\title{
I. Observations on the Straits of Malacca, in regard to natural history, geography, and commerce
}

\section{Hansel}

To cite this article: C. Hansel (1800) I. Observations on the Straits of Malacca, in regard to natural history, geography, and commerce, Philosophical Magazine Series 1, 7:27, 193-205, DOI: $10.1080 / 14786440008562574$

To link to this article: http://dx.doi.org/10.1080/14786440008562574

曲 Published online: 18 May 2009.

Submit your article to this journal $\sqsubset \pi$

Џ Article views: 5

Q View related articles $\widetilde{ }$ 


\section{PHILOSOPHICAL MAGAZINE.}

$A \cup G \cup S T 1800$

1. Obfervations on the Straits of Malacca, in regard to Natu. ral Hiflory, Geograpby, and Commerce. By C. HANsta*.

7

HE ifland of Pullo Pinang, which lies clofe to the coaft of Queda, between the fifth and fixth degree of northern latitude, and which now belongs to the Englifh Eaft India company, may ferve as a proof how well the Englifh underftand the art of eftablithing colonies, and bringing them in a thort time to a flourithing condition. About the year 1784 , the Malay king of Queda made a prefent of the whole ifland to Mr. James Light, the captain of a country thip trading thither, and the latter fold it to the Eaft India company, with the provifo that he fhould be appointed governor of it which was accordingly done, and he remained in that office till the end of the year 1795. The ifland was uninhabited, and entirely covered with wood. In order to erect a few houfes it was necefiary, therefore, to deftroy part of the wood, which was effected chiefly by means of fire.

This inand, which was now cal'ed Prince of Wales In,and, I vifited, for the firft time, in the year 1793, conrequently nine years after it had been taken poffeftion of by the Engtidh. At that period a beautiful town, of a pretty confiderable extent, and regularly laid out, had been built. A particular part of it was deftined for the Malays and other Afiatics, a great number of whom had already eftablifhed

; From Foumal fur Fabrik, Manufiur, Ekandlung, und Made, OEtober 氵799.

VoL, VII.

$\mathrm{C} c$

themfelves 
themfelves in the place. The market was well fupplied with fruits, fith, and other neceffaries. A confiderable trade had alfo begun to be carried on. Ships from Bengal brought hither opium, rice, and cotton, which were bartered for pepper, tin, betel-nuts, and gold-duft. All the company's fhips touch here in their voyage to China, as well as the large fleets from Bombay and Madras. The arrival of to many veffels makes this place a ftaple, where buying, felling and bartering are continually going on. The harbour, which is formed by the coaft of Queda and the eaft coaft of the ifland, is deep, and fecure from every wind. Thofe who are unacquainted with its geographical fituation imagine they are entering a river; fo fhort is its diftance from the continent. When viewed from the weft fide, the inand appears to be round, and its mountains may be feen at a con* fiderable difance. It is about thirty-five or thirty-fix miles in circumference: The prefent inhabitants have applied chiefly to the exiltivation of pepper, which is in a thriving condition, and promiles to turn out very advantageous. As the ifland produces excellent timber for thip-building, docks have been formed, and a great many veffels have already been launched.

A few miles from the town is a foreft, which, rifing gra. dually, covers the mountains behind it. From the fummit of the higheft of thefe mountains a large theam of water projects itfelf more than a hundred feet; with a prodigious roaring noife, on the rocks below, where, after bcing col lected in various natural bafons, it forms a fmalt rivulet, and then proceeds through the town, with a winding courfe, to the fea. One can hardly conceive how pleafant and refiefhing it is for thofe relaxed by the heat of the climate to bathe in one of thofe bafons, as the water is kept in a continual itate of coolnefs by the fhady branches of the trees, which form over them a fort of archess and defend them from the rays of the fun. The coolnefs of thefe groves, the majeftis roar of the waterfall, and the noife of a variety of unknown infects, make this an agreeable retreat to thofe who have $a$ tafte for the beauties of nature. In the year 1796 , countryHoufes were erected amidft thefe fairy groves, which, in 
the courfe of time, may be converted into Englifh gardens.

In the year 1789 the king of Queda took it in his head to demand back the ifland from the Englifh; and, as the latter thowed no inclination to comply with his defire, he affembled a confiderable army on the coaft oppofite to the inland, in order to lay fiege to it in form. That he might infpire his troops with more courage he gave them an entertainment, at which opium was not fpared. His Malayan majefty did not fail to get intoxicated along witth his warriors; and this being reported to the Englifh by means of their fpies, they attacked the Malays in their camp, killed their king, made a great flaughter among them, and thus put an end to the war. A regular ftone fort has fince been built, in which a garrifon is conftantly maintained of three battalions of fepoys and Europeans.

At firft, fhips that touched here were obliged to fail back the fame way they had entered; which was attended with this inconvenience, that thofe veffels deftined to proceed further through the Straits of Malacca eould not take advantage of a fair wind, becaufe it blows directly into the harbour, and by thefe means five or fix days were often loft. In the year 1791, however, captain Pophan * difcovered a paffage round the fouth-eaft end of the illand, by which this inconvenience is obviated.

To fail hence for Malacca there are two ways; one of which,' for large fhips, lies between two dangerous fandbanks, where a continual and rapid current, which runs ither north-weft or fouth-ealt, requires all the attention of

* Captair Popham is the gentleman who commanded the expedirion. of the Englifh to Oftend. As far as I remember, he commanded, in the year i 791 , a hip named I/ Treflo, which had been. fitted out at Oftend by the Englifh and lailed under the Tufcan flag. During the peace be obtained permiffon frum the Board of Admiralty, being then a licutenant in the navy, to enter into the merchant fervice; but as foon as the war broke ont, he was again employed on board a fhip of war. - H.

Captair Popham fuperintended lalt year the embarkation of the Ruffan ronops defined fur Holland, and affifted the operations of the Blivin army in that conntry. He received the hopour of knighthood from the eme pero Panl, being unake a knight of Mrita.--EDthe

$\mathrm{Ce}$ a 
the pilot to pafs in fafety. Nature, however, feems as if defirous to afford here every poffible affiftance, fince the Aru illands on the weft fide, which confift of fome finall uninhabited rocks, ferve the pilot as good marks to fteer by. When thefe difappear, the fummit of the mountain Parcelar is difcovered on the eaft fide, which mult be kept in a certain direction, according to the current, in order to pafs without danger. As navigators between thefe fand-banks have often to ftruggle with bad weather and contrary winds, it is impoffible to proceed but by continually heaving the lead, which is indeed attended with danger. The fecond paffage lies along the coaft through the fmall channel of Calum, which is farcely fo broad as the Elbe at Drefden. Nothing more beautiful can be conceived than this paflage, where veffels fometimes approach fo near the coaft that the bowfprit is often entangled among the branches of the trees. Birds of the moft hining and varicgated colours, tuknown to the Emropeans, are feen futtering around, while others delight the ear with their fong. As a fand-bank in the middle fhuts this paffage againt large thips, it is practicable only for thofe which draw very litlle water.

When veffels lave reached the northern part, nothing can be more pleafant than the navigation. They proceed along the coatt, from which the wind, when it blows from the land, wafts along with it the moft delicious aromatic odours. The months of the fmall channels, the different windings of the coatl, the bays which they form, and the land rifing like an amphtheatre, all together form the mot enchanting profpee. Notbing is wanting to complete the picture but habitations; for, in an extent of twenty or thirty miles, the only things of the kind that can be difcovered, even with a fpyingglafs, are a few fifhemen's huts.

At laft, after weathering a headland, you fuddenly difcover the town of Malacea, formerly belonging to the Dutch. It lies at the head of a bay, and, though fmall, is neat and well built. It is furrounded by beaufiful gardens and country= feats. No place in the world produces more valuable fruits. The ananas here are half an ell in length and a quarter of an ell in dianeter. They have an exceedingly fwret molieous 
tafte. The mangoftan, called in India the queen of fruits, is found here in great abundance, fo that from twa to three hundred of them may be purchafed for a dollar. They grow only in the ftraits of Malacca, Sunda, Banca, and in the inland of Java. They are found neither at Madras nor Bengal, nor in the Philippines or China. The ufual fruits of India thrive here better than any where elfe. The bay abounds with well-talted fifh, and excellent oyfters, crabs, cray-fih, \&c. Though this place lies nearly under the line, the climate is exceedingly healthful, and nothing is known here of thofe fevers and difeafes to which other Afiatic colonies are fubject. The temperature of the air is cooled by the fea and land breezes, which alternately prevail. The former begins between eleven and one in the forenoon, and blows very ftrongly till towards fix in the evening; at which time, however ftrong it may be, the lana-breeze aflumes its place, and continues till about eleven the rext day. By thefe means. an agreeable coolnefs is always preferved. At Calcutta, in Bengal, the heat is much more intenfe and infupportable, though it lies at the diftance of twenty-three degrees from the line; for it is not uncommon there to fee Fahrenheit's thermometer, in the fhade, during the months of April and May, at between eighty and ninety degrees. At the interval only when both winds ceafe, the heat is ftitting. The reafon of the land-breeze here being fo cool is, that, as Malacca is a peninfula, the wind always paffes over a portion of fea, whereas the land-breeze on the coaft of Coromandel paffes over the burning deferts of Perfia.

The frequent and exceedingly violent thunder-ftorms which take place here, contribute alfo very much to moderate the heat. They anife moftly in the north-weft, and bring with them fuch coolnefs that I remember having been feveral times fo cold that I was obliged to have recourfe to warmer clothing. The body here, indeed, is far more fenfible of the fmallef degree of cold than in the European climates, as the pores are kept fo open by the heat. Thefe ftorms are highly gratifying to the navigators bound to the Chinefe feas; for, as a fouth wind, except in a very few places, where the fea and land breezes fucceed each other regularlys 
regularly, prevails in the fraits, they are glad to fee fuch ftorms, which always begin to be formed in the north-weft. In the night, however, they cannot be ufed with fo much advantage, on account of the many fand-banks, illands, and even the coaft. itfelf, which muft be avoided. It has been remarked, that during thefe ftorms the magnetic reedle is in a continual ftate of perturbation; and I have heard the captain of an Englin Eaft Indiaman declare that he has feen, during a violent ftorm, the north end of the needle point directly fouth.

The European productions brought to Malacea for the purpoles of trade are confined to a very few articles. Rice, opium, white and coloured cottons, form the principal part of them. The Malays bring hither pepper, nutmegs, fago, rotangs, spanifh reeds, and gold-duft. The latter article is frit examined by the officers of the company, and then made up into froll packets in' Chinefe paper, bound round with a thread and impreffed with a feal containing Malay characters. Each packet contains a carty, and is worth from 460 to 500 piaftres. The Spaniards, who go from the Philippines to Mádras for the purpofes of trade, touch here always in order to exchange their piaftres for gold-duft, which they carry with them to the coaft of Coromandel, where, according to circumfances, they gain two per cent. Thefe packets, when fold, are never opened, bitt are taken on the feller's report; and no inftance is known of any frand ever having been practifed on fuch occafions. The fmall Spanifl reeds are fold for about eight piaftres per hundred, and pepper at fafteen piafires pex pickel of $x y^{\frac{1}{2}}$ Spanifh pounds. The cotton and opium brought hither are fold motly to the Dutch, who fell them afterwards to the Malays. The branch of trade, however, by which the inbabitants chicfy live, is fupplying the Rips which touch here with provifions, freth water, falted and freth fith, poultry and fruit. The price of fowls is generally a piaftre for eight or ten. Pine-apples are fold at the rate of from four to fix per piaftre. Thofe who are. acquainted with the number of the thips which pafs through thefe ftraits every year to China, the Philippines, the Souti Sea, Batavia, Borneo, Coringa, \&c. may form lome idea of the 
importance of this trade. The tavern where ftrangers refide is generally furrounded by a multitude of Malays having for fale, apes, parrots, cowries, Spanifh reeds, and various other articles. Among thefe people one may fee many of their kings, who are diftinguithed by a turban embroidered with gold, and who enter the tavern without receiving any particular marks of honour from the Europeans. The cafe is the fame with all the petty Indian kings, of whom too high ideas are entertained in Europe, but who in India are looked upon as littie better than corporals. It may be readily underftood that I here fpeak of the leffer princes; for the greater ones, fuch as the kings of Atcheen, Borneo, Pegu, \&c. are in general treated with more refpect.

The Dutch government, formerly eftablifhed here, confidered it as of great importance to clear the ftraits from the numerous Malay pirates by which it is infefted. For that purpofe it maintained a flotilla of cruifers and flat-bottomed veffels, which from time to time fought out the Malays in their places of retreat behind the fmall inlands in fhallow water, where their flat-bottomed veffels were of excellent fervice. The Malay prows generally carry a 24 -pounder in the bow; have only one maft, which can be lowered or railed at pleafure; and are furnithed with a rudder. They never attack $a$ veffel when there is wind, becaufe in that cafe it can manœuvre and make ufe of its cannon in every direction; but, if a calm take place, and they difcover a flip from their retreats, they then come out and attack the veffel behind and before, where they are out of reach of the cannon; maffacre, with their poifoned daggers called kris, all the white men on board; and carry off the blacks as flaves. A Dutch captain named Bloem, who commanded one of thefe cruifers, was a terror to the Malays. Being acquainted with their moft private retreats, he often furprifed them when they leaf expected it. They once. imagined they fhould be able to overcome him, and advanced againft him, during a calm, with fourteen of their prows; but before they got near him a fmall breeze fprung up, fo that he was enabled to direet his veflel, and to give them fuch a reception, that five or fix of the prows were funk, and others had their rudders thot 
avay; fo that they were obliged, to avoid total deftruction, to throw themfelves into the fea, and to fave themfelves by fwimming. The reft betook themfelves to flight; for the Dutch give the Malays no quarter.

of the laft inftance of this man's courage, which coft him his life, I mylelf was an eye-witnefs. The French frigate La Prudente, of thirty-fix guns, on board which $I$ was a prifoner, being in the ftraits of Malacca, about two o'clock on the $I 7$ th of July 1795 , the man at the maft-head calling out Vive ba Republique, announced that he faw a fail which feemed to be fteering towards us. As there was then little or no wind, the two veffels approached each other very flowly; and it was therefore near funfet before we could perceive that the ftrange fail was a veffel with two mafts. About ten at night, after I had lain down in my hammock, I was roufed by the drum beating to quatters. The officers near whofe birth my hammock was fung, immediately ftarted frorn theirs, and defired the citoyen prifonnier, meaning me, to do the fame. The fore-deck was cleared, and every prepatation made for battle. I then proceeded to the fore-deck, and obtained permifion to remain there: The two veffels by this time were fo near that they could fpeak each other. Our commandant hailed the ftrange fail, and afked to what nation the belonged. The anfwer was, that the was a Dutch thip of war.-Strike to the republican frigate La Prudente, and lower youtr fails.-Are you really French? faid the Ditch captàin.-Yes: take in your fails and drop your anchor, or I'll fink you.-I have no anchor on board, replied the Dutchman; but plenty of cannon; and at the moment we received a whole broadfite; which we infantly resurned. Several of the Dutchmen being killed, they then called out that they ftruck. Having taken poffeffion of the Dutch veffel, and fhifted the prifoners on board the frigate, we found the former to be the Java, of eighteen 9 -pounders; commanded by the beforementioned captain Bloem, who had that day failed from Malacea. A thot had carried away. part of his left breaft, but he ordered that the colours fhould not be ftruck till after his death.

The inhabitants of Malacea are a motley race, confifting 
of Europeans, creoles; mulattoes, black Chrifians (called commonly Portuguefe), Chinefe, and Malays. The Dutch and Germans eftablithed here, all have mulatio or creole wives, for I do not know one whofe wife is an European. The wife even of the laft governor, Abraham Couperus, was a mulatto." The cuftoms, manners, and drefs of thefe ladies, are all in the Malay tafte. The drefs which they ufe, both in the houfe and on public occafions, enfifts of a filk gown with wide feeves, which has a great refemblance to a powdering-gown. Their hair is twilted together and faftened on the crown of the head with a flver pin. In the houfe their favourite female naves fit at their feet; and when they go out to walk, or pay vifts, they accompany them, bearing a fmall filver box divided into different copartments, which contain certain articles indifpenfably neceffary for a Malay lady. Thefe articles are, betel, areka-nuts, chalk, a pair of fmall tongs, and a knife for fpreading the chalk on the betel-leaves, in which they wrap up finall bits of the areka-nut for the purpole of chewing them. The care which they beftaw on their domeftic economy confifts only in feeing the orders which they give to their flaves carried into execution. When a franger is invited to dinner, he is firft introduced into an apartment where he is treated with a pipe of tobacco. Female flaves then make their appearance, one of whom brings him a filver bafon for wafhing the hands, another a veffel containing water, and a third a towel. The company then fit down to table, and are waited on by the female laves belonging to the mafter of the houfe. They are attended alo fometimes by nufical naves, who, during the enteriainments perform pieces of mufic.

Slaves here, both male and female, a few excepted, are treated with great feverity. The mafter of one of the taverns, a Gcrman, named Kreis, born in Hohenlohe, is particulary diftinguined in this refpeet. I never entered his howe, which I did above ten times, without feeing punifhment inflicted on fome of his domeftics. If the cook had not prepared the dinner according to bis tafte, ho was immediately carried into the back court, when two other flaves ap. peared with bamboos in their hands, and belaboured him

Vor. VII.

$\mathrm{D}$ d

on 
on the pofteriors till his mafter, who walked up and down with his pipe in his mouth, told them to ftop. If the llaves did not execute his orders with fufficient feverity, he applied to their fhoulders a bamboo, which he always on thefe occafions carried" himfelf. "He always made it a rule when any ftranger who happened to be in his houfe interceded for his flaves, to punifh" them doubly. "Females naves even were not excepted from this correction, which was inflicted in the moft indecent manner. The Dutch government not only authorifed this feverity, but even put it in practice itfelf. A poor flave belonging to the fame Kreis had conceived an attachment to a female nave who refided in the neighbouring houfe, and belonged to one Adrian Koek. The lovers could only vift each other in the night-time, and for this purpofe the former was obliged to clamber over the roof of a penthoufe. "This nocturnal intercourfe being difcovered, Koek complained to the fifcal, and requefted that the llave might be punithed. Kreis, therefore, was obliged to give up his lave, and the fentence was, that he thould receive 500 blows with a bamboo; to be inflicted publicly. A ring was then put round each of his legs, between which an iron bar was fixed, fo that when he walked he was obliged to defcribe an arch with each foot, and in this ftate was fent back to his natter.

On the other hand, I muft obferve that it is hardly poffible, by the fevereft punifhment, to reftrain the profligacy and villainy of thefe men." What idea muft we entertain of a man, who, having been feverely punithed for drunkennefs, will; the very next day, take the key of the cellar from his mafter's clolet and get fo intoxicated as to be unable to fir from the fpot? To a circumftance of this kind I have niyfelf been a witnefs. The punithment, indeed, was cruel; for the culprit was made fat by the neck, middle, and legs, to iron rings faftened in the earth, and belaboured till the blood guthed from every part of his body, I was a withefs alfo to a more ftriking inftance, which fhows how little impreffion good treatment makes on thefe uncivilifed people. An opulent Englifinan, who had refided fome time at $\mathrm{Ma}$ Iacca, taking a fancy to one of Kreis's flaves, purchafed him 
for the fum of 300 piaftres. This flave was treated by his new mafte like a free man; he received money from him and permiffion to go abroad on afking leave, provided he remained to take care of the houfe in his matter's abfence. But this nave, unaccuitomed to freedom, notwithftanding every threat and admonition, when he got out of the houfe, would not return in the courfe of the whole day, and at laft, after being eight days in his new fervice, he ftole from his mafter a piece of money. His mafter endeavoured to make him confefs the theft, with a pronife of forgivenefs for this firft offence; but without fuccefs. This circumftance being told to Kreis, be confidered it as a good opportunity of exculpating himfelf from the charge of cruelty brought againft him by ftrangers, as he imagined he could now prove that mild treatment to fuch men would be entirely loft. He offered alfo, not only to take back the flave, but to force him to confefs: As the Englifhiman well knew that no one but his nave could be the thief, he delivered him over to Kreis, who tied him to a ladder; and then caufed the ufual punithment to be inflicted. When he had received two hundred blows, his body was bent, and in that condition he was thrown into a hole till the next morning, when the punifhment was renewed. He fill continued to hold out for fome time, but Kreis having threatened to continue the punifhment till he flould confers, he at length acknowledged the theft, but would not tell what he had done with the money. On the punifhment being once more applied, he confeffed that he had fold the piece of money for a fixteenth part of its worth to a Clinefe who was immediately fent for, and obliged to give it up. After this he remained in the fervice of Kreis, who declared that he had never after any occafion of complaint againft hin.

By what I have here faid, I do not mean to juftify the cruelties exercifed in this country, I only thought it neceffary to fiow, by fome examples, how cautious people ought to be in forming opinions on this fubject. The profligacy of thefe people is undonbtedly to be afcribed to their mafters, who do not pay the leaft attention to the formation of their moral character. They allow them to grow up like cattle, 
without taking care to give them any idea of religion, or of ather, knowledge, except what is immediately necellary to their mafters.

Thofe who poffefs a whole family of flaves, never fell any individual of that family, becaufe there have been numerous inftances in fuch cafes of the father's or mother's dying through grief, of becoming melancholy, or of deftroying themfelves. The names given to thefe flaves are generally thofe of the months in which they have been born or purchafed. The commerce by fea with the Malays is an armed commerce. All thips engaged in this trade carry a confiderable number of guns, and from ten to twenty fepoys or black foldiers. When a thip comes to anchor in any of the Malay ports, a beam is laid acrofs the deck before the maininaft to ferve as a barrier between the buyers and the fellers, and frick watch is at the fame time kept by the fepoys, with their arms loaded and their bayonets fixed. If a Malay have any particular bafinefs to tranfaet with the captain that requires lorger, time, he is admitted into the cabin in the after-part of the hip, but he mutt firf faffer himfelf to be fearched, to fee whether he has about him a knife or any kind of weapons. Neglect of this precaution has occafioned the lofs of many lives as well as veffels. The treacherrous Malay can never entertain any friendhip for the Europeans; even if they fhould hie in habits of intimacy with him for a dozen or twenty years, when a favourable opportunity occurs of promoting his own interef, he will make no ceremony of doing it by facrificing his old friend. I could here give many infances of this kind, but $I$ an convinced by what I have feen that the Europeans often give occafion to this villainy by their own conduct. Being one on board a large Bombay fits, botnd from Manilla to Madras, we difcovered in the firaits of Malacca five large Malay veffels, which, on difcovering us, anchored betwcen us and the land, except two, which were further ont at fea. As it was nearly calm, and the fhip made little way, the captain, in a fit of intoxication, fent one of his officers on board them to ath whence they came, and whither they were bound. Their anfwer was, that they came from Rio, were bound to $\mathrm{Ma}$ - 
lacca, and were laden with rotangs. This, however, did not fatisfy the captain, and he immediately began to fire among them. Being much alarmed at this conduct, they cut their cables and rowed with all their might towards the land, where they were in danger of running on fhore. In the mean time we pafked the other two, which being without us were not able to efcape, but, very fortunately, our captain did not obferve them on account of his ideas being deranged, and becaufe his attention was directed to the other fide. As foon as we had paffed, all the Malays on board bent themfelves three times. with their foreheads towards the deck, which in all probability was by way of returning thanks to Providence for the danger they had efcaped.

In the fraits there are a great many iflands which abound with excellent frelh water; but it cannot be at all times wed, as the Malays potfon the fprings: to fuch length do thefe men proceed in their hatred towards the Europeans. When fhips enter the ftraits, they are generally vifited by fmall Malay boats, which bring fin and tortoifes for fale. The tortoifes are of that kind called the green tortoife, which is three feet in length, about two in breadth, and weighs from two to three hundred pounds. A Spanifh dollar, a fmall quantity of rice, and a bottle of brandy, are in general the price of a tortoife and a certain number of fih. The Aleff of thefe tortoifes is well tafted and minch like that of veal, but difficult of digeftion. The eggs; on the other hand, a hundred of which are fometimes found in one animál, are a great delicacy, and made into foup. The greateft. advantage to feamen in purchafing thefe tortoifes is, that they live a long time: we kept many of them alive from three to four' weeks on the deck without any nourinment, and withoit any other care than throwing fea-water over them in the morning and evening. The whole ftrits are a real paradife interfperfed with a multitude of fmall iflands. Thofe who vifit them cannot help withing that they could fpend their whole lives on them, but while the Malays exift they muft be uninhabitable for Europeans: 